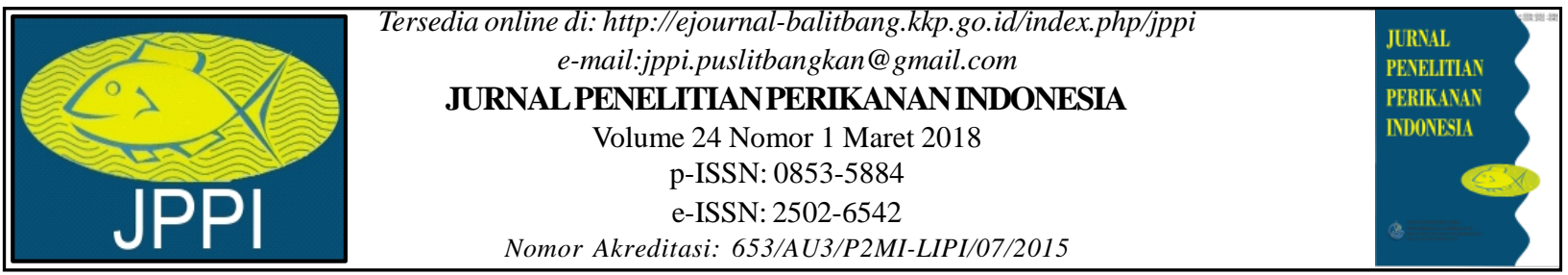

\title{
KUALITAS LINGKUNGAN PERAIRAN DAN POTENSI PRODUKSI IKAN KAWASAN KONSERVASI TERUBUK BENGKALIS (Tenualosa macrura Bleeker, 1852)
}

\section{WATER ENVIRONMENT QUALITY AND FISH POTENTION PRODUCTION IN BENGKALIS SHADS CONSERVATION (Tenualosa macrura Bleeker, 1852)}

\author{
Khairul Amri ${ }^{\star 1}$, Gathot Winarso² dan Muchlizar ${ }^{3}$ \\ 'Balai Riset Perikanan Laut, Kompl. Raiser Ikan Hias, Jl. Raya Bogor KM. 47, Cibinong-6912, Jawa Barat, Indonesia \\ ${ }^{2}$ Pusat Pemanfaatan Penginderaan Jauh (Pusfatja) LAPAN, JI. Lapan No.70, Pekayon, Pasar Rebo, Jakarta 13710 \\ ${ }^{3}$ Dinas Kelautan dan Perikanan Kab. Bengkalis, Jl. Pertanian, Bengkalis, Riau, 28714 \\ Teregistrasi I tanggal: 27 Nopember 2017; Diterima setelah perbaikan tanggal: 31 Januari 2018; \\ Disetujui terbit tanggal: 12 Februari 2018
}

\begin{abstract}
ABSTRAK
Terubuk Bengkalis (Tenualosa macrura) yang hidup di perairan Bengkalis dinyatakan terancam punah akibat eksploitasi berlebih dan penurunan kualitas perairan. Penelitian ini bertujuan untuk menganalisa kualitas perairan habitat terubuk Bengkalis, menggunakan data parameter oseanografi hasil pengukuran in-situ. Selain itu, data penginderaan jauh berupa citra Landsat 8 digunakan untuk analisa tutupan mangrove (hutan bakau) serta citra MODIS-Aqua (Moderateresolution Imaging Spectroradiometer) untuk analisis produktivitas primer (NPP). Penelitian dilaksanakan selama April-November 2015. Hasil penelitian menunjukkan total luas tutupan mangrove yang teridentifikasi citra Satelit Landsat 8 (2015) mencapai 11.736,2 Ha, berkurang sekitar 4.470,8 Ha dalam waktu 12 tahun (2003-2015) dengan laju kehilangan 372,5 Ha/tahun. Dari aspek oseanografi, kawasan konservasi ikan terubuk merupakan perairan dangkal dengan tingkat kecerahan rendah (0,54-0,95 m); suhu perairan relatif tinggi berkisar $29,15-31,87{ }^{\circ} \mathrm{C}$ (ratarata $\left.30^{\circ} \mathrm{C}\right)$ dan salinitas rata-rata tergolong rendah $(28,77-29,22 \mathrm{ppt})$. Nilai sebaran $\mathrm{pH}$ dan oksigen terlarut/DO juga rendah yakni $\mathrm{pH}$ 6,3-8,9 (rata-rata $\mathrm{pH}$ 7) dan $\mathrm{DO}$ 3,90-4,98 mg/l (di bawah Baku Mutu Air Laut). Komposisi substrat dasar didominasi lumpur, dengan prosentase 67,4-89,8\%, sehingga perairan ini umumnya keruh. Perairan ini tergolong subur (eutropik) dengan kelimpahan fitoplankton tinggi (23.584 - $95.616 \mathrm{sel} / \mathrm{l})$ terdiri dari 32-52 genera. Produktivitas primer juga tinggi, rata-rata $288,87 \mathrm{mgC} / \mathrm{m}^{2} /$ hari dengan potensi produksi ikan $3.680,2$ ton/tahun.
\end{abstract}

\section{Kata Kunci: Kualitas perairan; habitat terubuk; pengukuran in-situ; penginderaan jauh}

\begin{abstract}
Terubuk Bengkalis (Tenualosa macrura) is an endemic tropical shad fish that live in Bengkalis waters. This species has been declared endangered due to over exploitation and environmental degradation. The current research aimed to analyze the environmental quality of the species. The data used in this research were consited of in-situ measurement and remote sensing data: Landsat 8 Satellite imagery for mangrove cover observation and MODIS (Moderate-resolution Imaging Spectroradiometer) imagery for Net Primary Productivity (NPP). The results showed that the cover of mangrove vegetation along the coast of Bengkalis Island dentified by Landsat 8 Satellite imagery was 11.736,24 Ha. The total loss of cover mangrove vegetation is estimated about 4.470,83 $\mathrm{Ha}$, decreased drastically in 12 years (2003-2015) with a loss rate of $372.5 \mathrm{Ha}$ /year. The habitat of shad fish is shallow water category. The water quality was too turbid (brightness level 0.54-0.95 m); warm water temperature of $29 ., 15-31.87^{\circ} \mathrm{C}$ (average $30^{\circ} \mathrm{C}$ ); and low salinity $(28,77-29,22 \mathrm{ppt}$ ). The relatively low $\mathrm{pH}$ and dissolved oxygen content were determined: $\mathrm{pH}$ ranged between 6,3-8,9 (mean7) and
\end{abstract}


the DO: 3,90-4,98 mg/l (under the Sea Water Quality Standard). The substrat was dominated by mud $(67,4-89,8 \%)$ in Bengkalis Strait sub area due to the turbidity. However, these waters are euthropic level category with a high abundance of phytoplankton ranging from 23,584-95,616 cells/l and the species richness varies from 32-52 species. The primary productivity level of waters was also quite high was average of $288,87 \mathrm{mgC} / \mathrm{m}^{2} /$ day resulting an estimation of potential of fish biomass value about 3.680,2 ton/year.

\section{Keywords: Water quality; shads conservacion area; in-situ measurement; and remote sens- ing data}

\section{PENDAHULUAN}

Terubuk Bengkalis (Tenualosa macrura Bleeker, 1852) merupakan jenis ikan endemik yang hidup di perairan terbatas di sekitar estuaria Sungai Siak. Ikan ini dinyatakan terancam punah akibat pemanfaatan yang sangat intensif (Suwarso et al., 2003). Oleh karena target utama penangkapan nelayan adalah terubuk betina matang telur, mengakibatkan proses rekruitmen ikan ini terganggu (Efizon et al., 2012).

Kelestarian sumber daya terubuk juga terancam akibat penurunan kualitas perairan karena cemaran limbah kimiawi dan serbuk gergaji dari pabrik pengolahan kayu yang dibuang ke badan air Sungai Siak, sehingga terbawa sampai ke habitat ikan terubuk. Merta et al. (1999) menemukan limbah gergajian dalam lambung ikan terubuk. Selain itu, limbah pabrik pengolahan kayu dari Sungai Siak menyebabkan pendangkalan di estuaria dan perairan selat: Selat Bengkalis, Selat Padang dan Selat Lalang (Wahyu, 2015). Dilihat dari segi kualitas perairan sudah mengalami penurunan ditandai oleh rendahnya tingkat kecerahan perairan dan $\mathrm{pH}$ perairan estuaria dan tingginya tingkat kekeruhan air dengan kandungan partikel terlarut (TSS/total suspended solid) yang tinggi (Fajri et al., 2013). Menurut Setiawan (2008), struktur komunitas macro zoobenthos tertentu dapat dijadikan bioindikator kualitas lingkungan perairan.

Untuk mempertahankan keberlanjutan sumber daya terubuk, berbagai upaya telah dilakukan pemerintah pusat maupun daerah. Tujuannya menjaga agar populasi ikan peruaya di estuaria ini tidak punah, namun dengan tetap memperhatikan kepentingan pemanfaatan potensi ekonominya. Dalam skala lokal telah dilakukan perlindungan habitat dan pengaturan pemanfaatannya melalui Peraturan Bupati Bengkalis No.15 Tahun 2010 (Wahyu, 2015). Pada tingkat nasional, Pemerintah Pusat memberikan status perlindungan terbatas berdasarkan Keputusan Menteri Kelautan dan Perikanan No.59/Men/2011 (Darmawan et al., 2014). Selanjutnya, Pemerintah Provinsi Riau mengeluarkan Peraturan Gubernur No. 78/2012 tentang Konservasi Perikanan Ikan Terubuk (Efizon et al., 2013).
Dari sisi daratan, tekanan terhadap habitat terubuk juga semakin tinggi akibat kerusakan mangroves. Mangroves memiliki kemampuan ekologis mendukung eksistensi lingkungan dan keberlangsungan hidup biota akuatik, termasuk keberlangsungan hidup larva ikan terubuk. Fikri (2006) menyebutkan penyusutan luasan mangroves di sepanjang pesisir Bengkalis selama dua dekade terakhir cukup signifikan, sehingga meningkatkan abrasi dan berdampak pada kekeruhan perairan. Dengan demikian, informasi besarnya perubahan luasan tutupan mangroves perlu diketahui sebagai dasar pertimbangan dalam upaya perbaikan kondisi habitat ikan terubuk.

Produktivitas primer menunjukkan jumlah energi cahaya yang diubah menjadi energi kimia oleh autotrof (fitoplankton) suatu ekosistem, selama periode waktu tertentu (Campbell, 2002). Produktivitas primer juga diartikan jumlah gram karbon dalam material hidup yang dihasilkan dalam satu meter kuadrat kolom air per hari ( $\mathrm{g} \mathrm{C} / \mathrm{m}^{2} /$ hari) atau dalam satu meter kubik per hari ( $\left(\mathrm{g} \mathrm{C} / \mathrm{m}^{3} /\right.$ hari) (Levinton, 1982). Menurut Parson et al. (1984) nilai NPP (Net Primary Productivity / Produktivitas Primer Bersih) menggambarkan kesuburan perairan yang dapat menentukan daya dukung perairan. Oleh karena berada pada lokasi yang rentan terhadap ancaman cemaran, maka pengamatan terhadap kualitas lingkungan perairan di kawasan konservasi ikan terubuk penting dilakukan. Informasi terkait dengan daya dukung perairan dari analisa nilai NPP dapat digunakan untuk estimasi potensi produksi (standing stock).

Penelitian ini membahas kualitas lingkungan kawasan konservasi ikan terubuk, mencakup perubahan luasan tutupan mangrove; kondisi oseanografi dan tingkat produktivitas primer perairan (NPP) dari data pengukuran in-situ dan penginderaan jauh.

\section{BAHAN DAN METODE Lokasi Penelitian dan Jenis Data}

Penelitian ini dilaksanakan di perairan kawasan konservasi ikan terubuk di perairan Bengkalis mencakup Selat Bengkalis, Selat Padang/Pakning, dan Selat Lalang (Gambar 1). Data kualitas lingkungan 
perairan yang diamati meliputi: parameter oseanografi, NPP (Net Primary Productivity), dan luasan tutupan mangrove. Parameter oeanografi mencakup kedalaman perairan, kecerahan perairan, temperatur, salinitas, $\mathrm{pH}$, oksigen terlarut/DO, substrat, dan kelimpahan plankton.

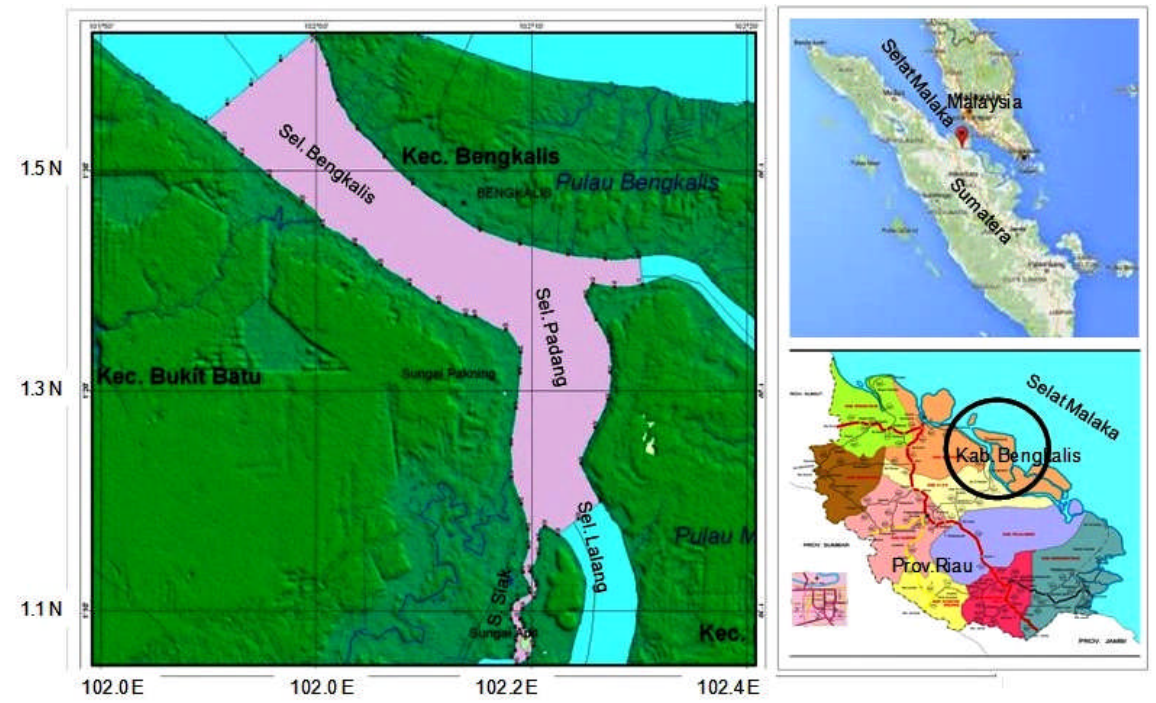

Gambar 1. Lokasi penelitian di kawasan konservasi ikan terubuk bengkalis.

Figure 1. Map of research location in terubuk conservation area, Bengkalis.

\section{Perolehan Data}

Luasan tutupan mangrove diperoleh dari analisa citra Satelit Landsat 8 yang diperoleh dari LAPAN (Lembaga Penerbangan dan Antariksa Nasional). Ground check untuk validasi mangrove di lapangan, dilakukan Agustus 2015 di beberapa lokasi di Pulau Bengkalis (Kec. Bengkalis dan Kec. Bantan) dan sisi timur Pulau Sumatera (Kec. Siak Kecil dan Kec. Bukit Batu). Pengukuran data oseanografi dilakukan dengan menggunakan kapal KM. Tenualossa (20 GT) milik Dinas Kelautan dan Perikanan Kab. Bengkalis pada April-November 2015. Data NPP dihitung dari analisa citra sensor visible Satelit MODIS-Aqua (Moderateresolution Imaging Spectroradiometer) dari Ocean Biology Processing Group NASA dan diproses dengan perangkat lunak WIM (http:// oceandata.sci.gsfc.nasa.gov/).

\section{Pengolahan dan Analisa Data Tutupan Mangrove}

Identifikasi mangrove menggunakan komposit band RGB 564 (spektrum visible dan near infrared) gabungan dua scene citra Satelit Landsat 8 (2 scene: $127 / 59$ dan 126/59). Tahapan pengolahan terdiri dari: pengolahan awal yaitu koreksi citra (koreksi radiometrik, atmosferik dan geometrik); klasifikasi; serta interpretasi (Gambar 2). Metode klasifikasi meliputi unsupervised dan supervised menggunakan K-Means (pada software ENVI). Untuk menghitung nilai kerapatan mangrove digunakan rasio kanal infra merah dekat (NIR) dan kanal merah (Red) (Green et al., 2000) dengan formula sbb:

$$
\text { NDVI }=\frac{(\text { infrared }- \text { red })}{(\text { infrared }+ \text { red })}
$$

dimana, NDVI adalah nilai Normalized Difference Vegetation Index, infrared adalah band 5 dan red adalah band 4 citra Landsat 8 .

Nilai kerapatan tajuk mangrove ditentukan menggunakan perhitungan NDVI. Nilai kelas NDVI diklasifikasi ulang (reclass) menjadi tiga kelas, yaitu kerapatan jarang, sedang dan lebat. Perhitungan interval kelas kerapatan berdasarkan rumus Strurges (1926) sebagai berikut:

$$
K L=\frac{x t-x r}{k}
$$

dimana, $\mathrm{KL}$ adalah kelas interval, $\mathrm{xt}$ adalah nilai tertinggi, $x$ r adalah nilai terendah dan $\mathrm{k}$ adalah jumlah kelas yang diinginkan.

Untuk mengetahui tingkat akurasi dari hasil klasifikasi digunakan metode uji ketelitian klasifikasi confussion matrik mengacu pada Short (1982) dan Purwadhi (2001) dengan formula sebagai berikut:

$$
\begin{aligned}
M A= & \begin{array}{l}
(\text { Xcr pixel }) /(\text { Xcr pixel }+ \text { Xo pixel }+ \text { Xco } \\
\text { pixel })^{\star} 100 \% \ldots \ldots \ldots \ldots \ldots \ldots \ldots \ldots \ldots \ldots \ldots . .(3)
\end{array}
\end{aligned}
$$

dimana, $M A=$ ketelitian pemetaan sebaran mangrove (mapping accuracy); $\mathrm{Xcr}=$ jumlah kelas $\mathrm{X}$ yang terkoreksi; $\mathrm{Xo}=$ jumlah kelas $\mathrm{X}$ yang masuk ke kelas lain (omisi); dan $\mathrm{Xco}=$ jumlah kelas $\mathrm{X}$ tambahan dari kelas lain (komisi). 


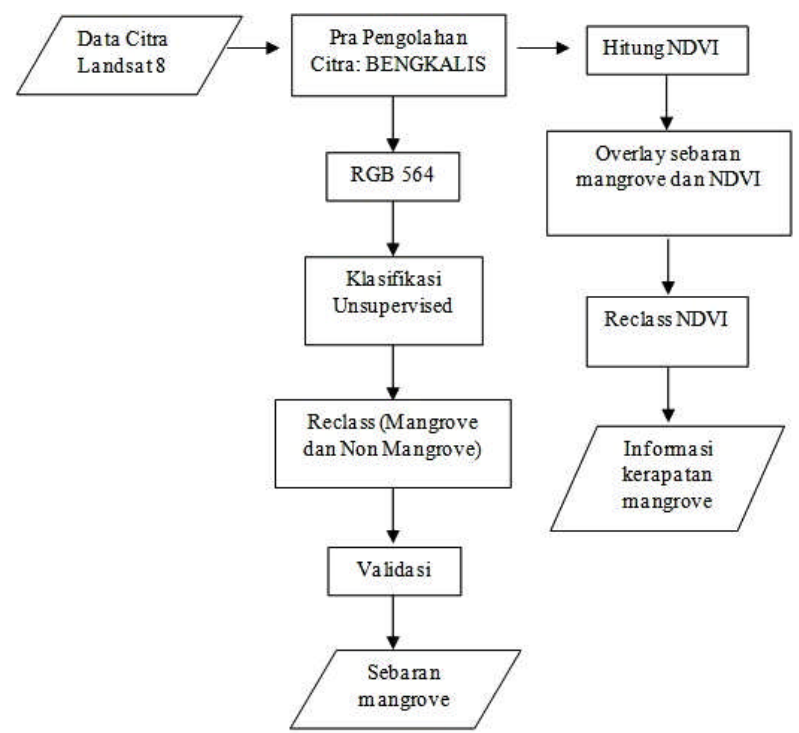

Gambar 2. Diagram alir pengolahan citra untuk klasifikasi luasan mangrove.

Figure 2. Flow chart of image processing for magroves classification.

\section{Parameter Oseanografi}

Parameter oseanografi diolah untuk mendapatkan nilai kisaran dan rata-rata bulanan berdasarkan lokasi pengamatan. Kemudian ditabulasi untuk memudahkan pembacaan dan membandingkan nilai masing-masing parameter.

\section{Produktivitas Primer Bersih}

Perhitungan NPP (Net Primary Productivity) berdasarkan Vertical Generalized Productivity Model (Behrenfeld and\& Falkowski, 1997) sebagai berikut: $N P P=0,66125 x P_{\text {opt }}^{B} x \frac{E_{O}}{E_{O}+4,1} x C h l x Z_{e u} x D L$

dimana, $\mathrm{Chl}=$ konsentrasi klorofil-a di permukaan $\left(\mathrm{mg} / \mathrm{m}^{3}\right) ; \mathrm{DL}=$ panjang hari (dalam desimal jam); $\mathrm{E}_{0}=$ PAR (Photosyntetic Available Radiation) permukaan harian (mol quanta $/ \mathrm{m}^{2} /$ hari); Zeu=Kedalaman zona euphotic $(\mathrm{m})$; dan PBopt=Laju fiksasi karbon optimum ( $\mathrm{mgC} / \mathrm{mg} \mathrm{Chl/hari).}$
PB-opt dihitung dari suhu permukaan laut (SPL) dengan rumus polinomial 7 tingkat (Behrenfel \& Falkowski, 1997). Jadi input dari NPP adalah konsentrasi klorofil-a, SPL dan PAR. Selanjutnya, dari nilai NPP dapat dilakukan penghitungan estimasi potensi sumber daya ikan (standing stock) menggunakan rumus Parson et al. (1984) sbb:

$\mathrm{P}=\mathrm{BE}^{\mathrm{n}}$

di mana, $\mathrm{P}=$ Produksi ikan $\left(\mathrm{mgC} \mathrm{m}^{-2} \mathrm{thn}^{-1}\right)$; $\mathrm{B}=$ Produksi primer /NPP $\left(\mathrm{gC} \mathrm{m}^{-2}\right.$ thn $\left.^{-1}\right) ; \mathrm{E}=$ Efisiensi ekologi (\%); dan $n=J u m l a h$ tingkatan tropik.

Untuk mendapatkan jumlah produksi atau potensi ikan di kawasan konservasi ikan terubuk, maka produksi ikan (dalam $\mathrm{mgC} \mathrm{m}^{-2} \mathrm{thn}^{-1}$ ) dikalikan luas area kawasan. Produksi ikan (ton), diperoleh berdasarkan asumsi yang dikemukakan Parson et al. (1984) bahwa perbandingan berat basah ikan dan berat karbon sesuai jenis wilayah lautnya, seperti tertera dalam Tabel 1.

Tabel 1. Estimasi produksi ikan (Ryther 1969 dalam Parson et al., 1984)

Table 1. Estimation of fish production (Ryther 1969 vide Parson et al., 1984)

\begin{tabular}{|c|c|c|c|c|}
\hline $\begin{array}{c}\text { Wilayah Laut/Type of Sea } \\
\text { area }\end{array}$ & $\begin{array}{c}\text { Rata-rata } \\
\text { Produktivitas } \\
\text { Primer/Average of } \\
\text { Primary productivity } \\
\left(\text { (gC m }^{-2} \text { thn/year }{ }^{-1}\right)\end{array}$ & $\begin{array}{c}\text { Tingkatan } \\
\text { Tropik/Tropic } \\
\text { level }\end{array}$ & $\begin{array}{c}\text { Efisiensi } \\
\text { Ekologi/Ecology } \\
\text { efficiency (\%) }\end{array}$ & $\begin{array}{c}\text { Produksi lkan } \\
\text { /Fish } \\
\text { production }(\mathrm{mgC} \\
\left.\mathrm{m}^{-2} \text { thn } / \text { year }^{-1}\right)\end{array}$ \\
\hline Lautan/Ocean & 50 & 5 & 10 & 0,5 \\
\hline $\begin{array}{l}\text { Landas } \\
\text { Kontinent/Continental } \\
\text { shelf }\end{array}$ & 100 & 3 & 15 & 340 \\
\hline Upwelling area & 300 & 1.5 & 20 & 36.000 \\
\hline
\end{tabular}




\section{HASIL DAN BAHASAN}

Hasil

\section{Kondisi Tutupan Mangrove}

Kenampakan khas mangrove dari 2 scene citra komposit RGB 564 Landsat 8 (Gambar 3-a) adalah objek berwarna coklat (Gambar 3-b). Enam dari delapan kecamatan memiliki mangrove, sementara dua kecamatan di P. Sumatera (Kec. Mandau dan Pinggir) tidak memiliki garis pantai sehingga tidak terdapat mangrove. Dua kecamatan di P. Rupat (Rupat dan Rupat Utara) tidak dilakukan penghitungan karena tidak terkait dengan habitat terubuk. Total luasan mangroveyang teridentifikasi mencapai $11.736,2 \mathrm{Ha}$, masingmasing seluas 10.568,2 Ha di P. Bengkalis (Kec. Bengkalis dan Bantan) dan $1.168 \mathrm{Ha}$ di sisi timur P. Sumatera (Kec. Siak Kecil dan Bukit Batu) (Tabel 2).

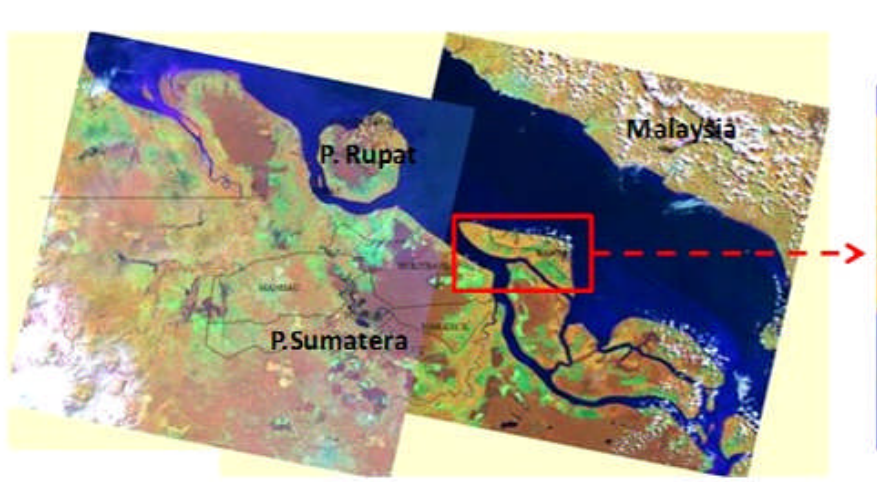

(a)

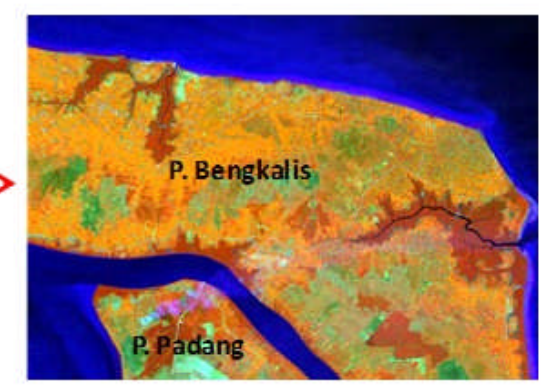

(b)

Gambar 3. Citra Landsat 8 (scene 127/59 dan 126/59) Kab. Bengkalis. (a) garis hitam batas kecamatan; dan (b) penampakan mangrove pada sampling area citra komposit RGB 564.

Figure 3. Landsat 8 imagery (scene 127/59 dan 126/59 of Bengkalis). (a) black line distrik border; and (b) mangroves identification in sampling area by composit image RGB 564.

Mangrove terluas $(6.660 \mathrm{Ha})$ terdapat di Kec. Bantan di sisi Sel. Malaka. Luas tutupan mangrove di sepanjang pantai yang menghadap langsung ke habitat konservasi ikan terubuk (Sel. Bengkalis dan
Sel. Padang) sekitar 5.076,1 Ha, dimana seluas 3.908 $\mathrm{Ha}$ berada di Kec. Bengkalis (P. Bengkalis) dan seluas 1.111,6 Ha di Kec. Bukit Batu serta 56,42 Ha di Kec. Siak Kecil (P.Sumatera) (Gambar 4).

Tabel 2. Luas mangrove sekitar kawasan konservasi terubuk Bengkalis dari citra Landsat 8 pada 2015

Table 2. Coverage of mangroves at terubuk conservation area taken from Landsat 8 imagery analyze in 2015

\begin{tabular}{ccccc}
\hline No. & Lokasi/Location & Kecamatan/Districts & $\begin{array}{c}\text { Luas } \\
\text { Mangrove/Mangroves } \\
\text { coverage (Ha) }\end{array}$ \\
\hline 1 & Pulau & Kecamatan Bantan & $6.660,14$ \\
& Bengkalis/Bengkalis & & $3.908,03$ \\
& Island & Kecamatan Bengkalis & Sub Total & $10.568,17$ \\
\hline 2 & Pulau & Kecamatan Bukit Batu & & $1.111,65$ \\
& Sumatera/Sumatra & & 56,42 \\
& Island & Kecamatan Siak Kecil & Sub Total & $1.168,07$ \\
\hline & & Total & $11.736,24$ \\
\hline
\end{tabular}




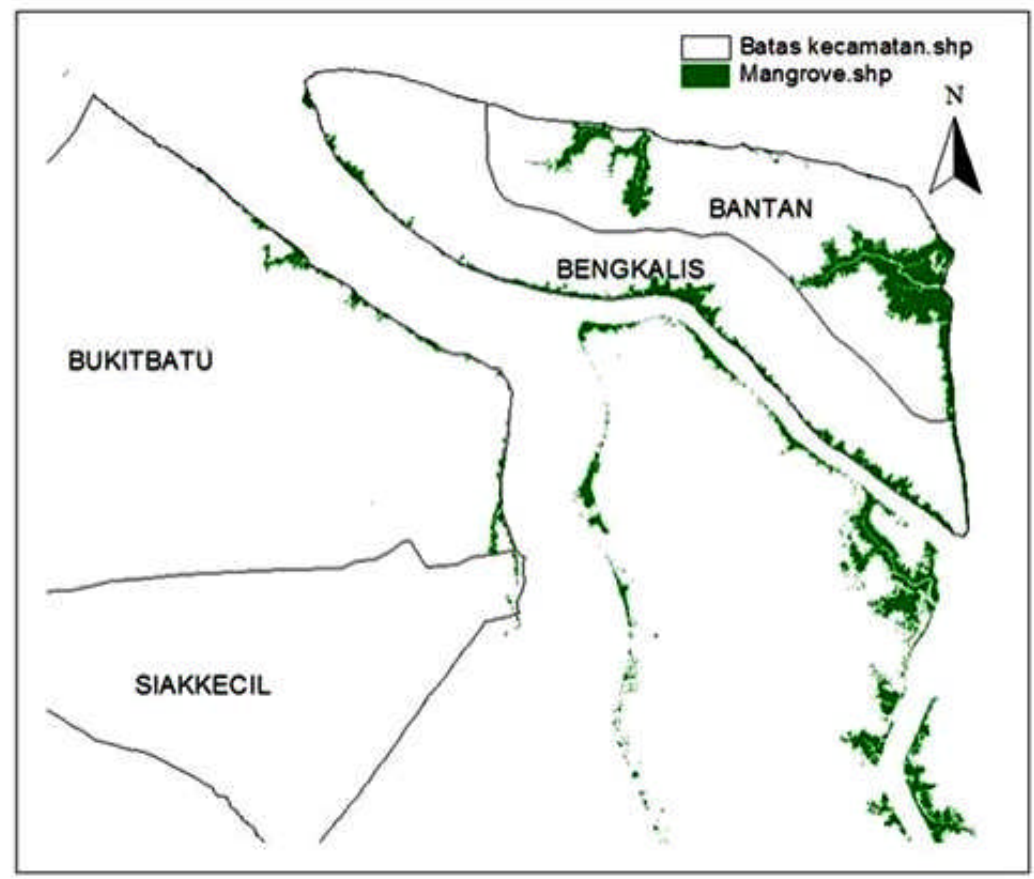

Gambar 4. Sebaran hutan mangrove (warna hijau) di Kab Bengkalis setiap Kecamatan.

Figure 4. Distribution of mangroves (green color) in Bengkalis Districts.

Dari pola sebarannya (Gambar 4), tutupan mangrove di Kec. Bantan terkonsentrasi di aliran sungai dan muara sungainya dan hanya sedikit yang teridentifikasi di pesisir Sel. Malaka. Tutupan mangrove di pantai bagian utara Kec. Bengkalis pada sisi yang menghadap Sel. Malaka, juga tidak terdeteksi. Mangrove dalam luasan terbatas ditemukan di sepanjang pantai Sel. Bengkalis dan Sel. Padang/ Pakning yang menjadi habitat ikan terubuk, baik dari sisi Pulau Bengkalis (Kec. Bengkalis) maupun sisi Pulau Sumatera (Kec. Bukit Batu dan Kec. Siak Kecil). Secara umum dapat dikatakan tutupan mangrove di sekitar habitat ikan terubuk sangat sedikit dan hanya terdapat di lokasi tertentu saja.

\section{Kondisi Oseanografi}

Habitat kawasan konservasi terubuk yang terdiri dari sub area perairan Selat Bengkalis, Selat Padang/ Pakning, muara Sungai Siak dan Selat Lalang tidak hanya menjadi lokasi penangkapan ikan bagi nelayan, juga berfungsi sebagai jalur transportasi laut dan kegiatan ekonomi lainnya. Selat Padang/Pakning yang berada di depan muara Sungai Siak, menjadi lokasi tambat labuh dan pengisian BBM kapal tanker. Sementara Selat Lalang, selain menjadi lokasi labuh tambat kapal tanker, juga terdapat anjungan pengeboran minyak. Aktifitas tersebut menyumbang penurunan kualitas perairan berupa kekeruhan dan cemaran minyak. Nilai kisaran dan rata-rata parameter oseanografi di perairan kawasan konservasi ikan terubuk ditampilkan dalam Tabel 3.

Dari aspek parameter fisik (Tabel 3), terlihat bahwa perairan kawasan konservasi ikan terubuk merupakan perairan dangkal (estuaria), dengan kedalaman berkisar antara 8,15-17,70 m. Selat Padang merupakan perairan terdangkal dan Selat Lalang terdalam. Tingkat kecerahan perairan sangat rendah, rata-rata berkisar 0,54-0,95 m. Selat Lalang merupakan perairan yang paling keruh dan Sel. Bengkalis memiliki tingkat kecerahan tertinggi. Suhu perairan berkisar $29,15-31,87^{\circ} \mathrm{C}$ dengan nilai ratarata $30^{\circ} \mathrm{C}$ hampir sama di semua lokasi. Komposisi substrat menunjukkan dasar perairannya didominasi lumpur (debu), dengan komposisi dominan debu di Selat Bengaklis $(67,4-89,8 \%)$. 
Tabel 3. Parameter oseanografi habitat konservasi ikan terubuk pada 2015

Table 3. Parameter of oceanographyc at terubuk conservation area in 2015

\begin{tabular}{|c|c|c|c|c|c|}
\hline \multirow[t]{2}{*}{ NO. } & \multirow{2}{*}{\multicolumn{2}{|c|}{$\begin{array}{c}\text { PARAMETER } \\
\text { OSEANOGRAFI/OCEANOGRAPHYC } \\
\text { PARAMETER }\end{array}$}} & \multicolumn{3}{|c|}{$\begin{array}{l}\text { LOKASI PERAIRAN/LOCATION OF WATERS } \\
\text { Selat }\end{array}$} \\
\hline & & & $\begin{array}{l}\text { Selat } \\
\text { Bengkalis }\end{array}$ & Selat Padang & Selat Lalang \\
\hline 1 & Kedalaman (m) & $\begin{array}{l}\text { Kisaran } \\
\text { Rerata }\end{array}$ & $\begin{array}{r}8,15-32,15 \\
15\end{array}$ & $\begin{array}{r}12,14-18,00 \\
14\end{array}$ & $\begin{array}{r}14,50-17,70 \\
16\end{array}$ \\
\hline 2 & Kecerahan (m) & $\begin{array}{l}\text { Kisaran } \\
\text { Rerata } \\
\end{array}$ & $\begin{array}{r}0,50-2,50 \\
0,95 \\
\end{array}$ & $\begin{array}{r}0,30-1,50 \\
0,7 \\
\end{array}$ & $\begin{array}{r}0,30-2,00 \\
0,54 \\
\end{array}$ \\
\hline 3 & Komposisi Substrat (\% & & & & \\
\hline & Pasir & Kisaran & $2,7-25,2$ & $5,5-53,3$ & $6,9-86,7$ \\
\hline & $\begin{array}{r}\text { Debu } \\
\text { Liat }\end{array}$ & $\begin{array}{l}\text { Kisaran } \\
\text { Kisaran }\end{array}$ & $\begin{array}{r}67,4-89,8 \\
7,3-12,4 \\
\end{array}$ & $\begin{array}{r}38,3-85,0 \\
8,3-10,4 \\
\end{array}$ & $\begin{array}{r}10,6-85,8 \\
2,7-10,1 \\
\end{array}$ \\
\hline 3 & Suhu $\left({ }^{0} \mathrm{C}\right)$ & $\begin{array}{l}\text { Kisaran } \\
\text { Rerata }\end{array}$ & $\begin{array}{r}29,77-30,70 \\
30,2\end{array}$ & $\begin{array}{r}29,15-31,15 \\
30,02 \\
\end{array}$ & $\begin{array}{r}29,57-31,87 \\
30,61\end{array}$ \\
\hline 4 & Salinitas (ppt) & $\begin{array}{l}\text { Kisaran } \\
\text { Rerata }\end{array}$ & $\begin{array}{r}27,57-31,07 \\
29,82 \\
\end{array}$ & $\begin{array}{r}26,50-31,25 \\
28,77 \\
\end{array}$ & $\begin{array}{r}27,00-29,83 \\
28,86 \\
\end{array}$ \\
\hline 5 & $\mathrm{pH}$ & $\begin{array}{l}\text { Kisaran } \\
\text { Rerata }\end{array}$ & $\begin{array}{r}6,5-8,93 \\
7,72 \\
\end{array}$ & $\begin{array}{r}6,38-8,85 \\
7,41 \\
\end{array}$ & $\begin{array}{r}6,43-8,91 \\
7,71 \\
\end{array}$ \\
\hline 6 & $\mathrm{DO}(\mathrm{mg} / \mathrm{l})$ & $\begin{array}{l}\text { Kisaran } \\
\text { Rerata }\end{array}$ & $\begin{array}{r}4,27-4,98 \\
4,58\end{array}$ & $\begin{array}{r}3,99-4,22 \\
4,07\end{array}$ & $\begin{array}{r}3,90-4,30 \\
4,01\end{array}$ \\
\hline 7 & Fitoplankton & & & & \\
\hline & $\begin{array}{l}\text { Kelimpahan }(\mathrm{Sel} / \mathrm{l}) \\
\text { Jumlah jenis/taxa }\end{array}$ & $\begin{array}{l}\text { Kisaran } \\
\text { Kisaran }\end{array}$ & $\begin{array}{r}24.589-95.616 \\
32-50\end{array}$ & $\begin{array}{r}24.900-86.652 \\
32-52\end{array}$ & $\begin{array}{r}23.584-83.996 \\
33-51\end{array}$ \\
\hline
\end{tabular}

Dari aspek parameter kimia (Tabel 3), salinitas tergolong rendah, rata-rata berkisar antara 28,77 29,22 ppt. Dari nilai sebaran rata-ratanya, massa air di Sel. Padang/Pakning memiliki salinitas paling rendah, karena posisinya persis berada di depan muara Sungai Siak dan Sungai Siak Kecil, menyebabkan nilai sebaran $\mathrm{pH}$ juga relatif rendah, berkisar antara $\mathrm{pH}$ 6,3-8,9 (rata-rata 7,4) karena besarnya pengaruh massa air gambut yang karakteristiknya asam. Sebaliknya, massa air Selat Bengkalis yang berhubungan langsung dengan Selat Malaka, memiliki nilai sebaran rata-rata salinitas relatif lebih tinggi $(29,82 \mathrm{ppt})$ dengan nilai sebaran $\mathrm{pH}$ yang juga lebih tinggi (rata-rata 7,7). Nilai sebaran oksigen terlarut/DO umumnya rendah berkisar $3,90-4,98 \mathrm{mg} /$ I. DO terendah di Selat Padang dan Selat Lalang (masing-masing 4,07 mg/l dan 4,01 mg/l) karena pengaruh massa air Sungai Siak, sementara Selat
Bengkalis yang mendapat pengaruh massa air laut dari Selat Malaka memiliki nilai sebaran rata-rata DO lebih tinggi $(4,58 \mathrm{mg} / \mathrm{l})$. Dari aspek parameter biologi (Tabel 3), perairan ini memiliki kelimpahan fitoplankton yang cukup tinggi, berkisar 23.584 - 95.616 sel//, terdiri dari 32-52 genera.

\section{Produktivitas Primer Perairan}

Variasi bulanan NPP selama periode Januari 2014Mei 2015 (Tabel 4) berkisar antara 2.089-4.169 mgC/ $\mathrm{m}^{2} /$ hari atau rata-rata $2.804 \mathrm{mgC} / \mathrm{m}^{2} /$ hari (2014) dan $2.399-3.311 \mathrm{mgC} / \mathrm{m}^{2} /$ hari atau rata-rata $2.963 \mathrm{mgC} /$ $\mathrm{m}^{2} /$ hari (2015) dengan pola sebaran bulanan ditampilkan pada citra NPP (Lampiran 1). Dari nilai tersebut terlihat bahwa sebaran rata-rata NPP per hari pada 2015 lebih tinggi dibandingkan dengan 2014, menandakan pada 2015 perairannya lebih subur.

Tabel 4. Nilai sebaran bulanan NPP di perairan Bengkalis pada 2014-2015

Table 4. Monthly distribution of NPP in Bengkalis waters 2014-2015

\begin{tabular}{|c|c|c|c|c|c|c|c|c|c|c|c|c|}
\hline \multirow[t]{2}{*}{$\begin{array}{l}\text { ГAHUN/ } \\
\text { YEAR }\end{array}$} & \multicolumn{12}{|c|}{$\begin{array}{c}\text { BULAN/MONTH } \\
\left(\mathrm{mgC} / \mathrm{m}^{2} / \text { day }\right) \\
\end{array}$} \\
\hline & JAN & FEB & MAR & APR & MEI & JUN & JUL & AGS & SEP & OKT & NOV & DES \\
\hline $\begin{array}{l}2014 \\
2015\end{array}$ & $\begin{array}{l}4.169 \\
2.884\end{array}$ & $\begin{array}{l}2.630 \\
2.399 \\
\end{array}$ & $\begin{array}{l}2.399 \\
3.162\end{array}$ & $\begin{array}{l}2.089 \\
3.311\end{array}$ & $\begin{array}{l}2.512 \\
3.059\end{array}$ & 2.884 & 3.020 & 2.089 & 2.291 & 4.169 & 2.884 & 2.512 \\
\hline $\begin{array}{l}2014 \\
2015\end{array}$ & $\begin{array}{r}\text { Kis } \\
2.089-4 \\
2.399-3\end{array}$ & $\begin{array}{l}\operatorname{ran} \\
160 \\
311\end{array}$ & $\begin{array}{r}\text { Rate } \\
2.8 \\
2 .\end{array}$ & $\begin{array}{l}\text { rata } \\
04 \\
63\end{array}$ & & & & & & & & \\
\hline
\end{tabular}


Fluktuasi sebaran bulanan NPP menunjukkan pola yang cenderung tinggi pada awal tahun (Januari) kemudian menurun (Februari) dan mengalami kenaikan pada Maret sampai dengan Juli (Gambar 5), selanjutnya menurun pada Agustus dan meningkat lagi pada Oktober, kemudian November-Desember cenderung menurun.Varasi fluktuasi nilai sebaran tersebut tampaknya tidak mengikuti siklus moonson tetapi lebih dipengaruhi run off dari sungai.
Jika dikoversi menjadi potensi biomassa ikan (rumus No.5), dari nilai produktivitas primer/NPP tahun 2014-2015 yang berkisar 208,9-416,9 gC m m thn $^{-1}$ $\left(288,9 \mathrm{gC} \mathrm{m}^{-2} \mathrm{thn}^{-1}\right)$ dan dengan memperhitungkan luasan perairan $\left(424,7 \mathrm{~km}^{2}\right)$, maka didapatkan potensi biomassa ikan di perairan ini berkisar 626,7-10.399,2 $\mathrm{mgC} \mathrm{m}^{-2}$ atau setara dengan $5.322,8-10.622,7$ ton (rata-rata 7.360,4 ton/tahun) (Tabel 5).

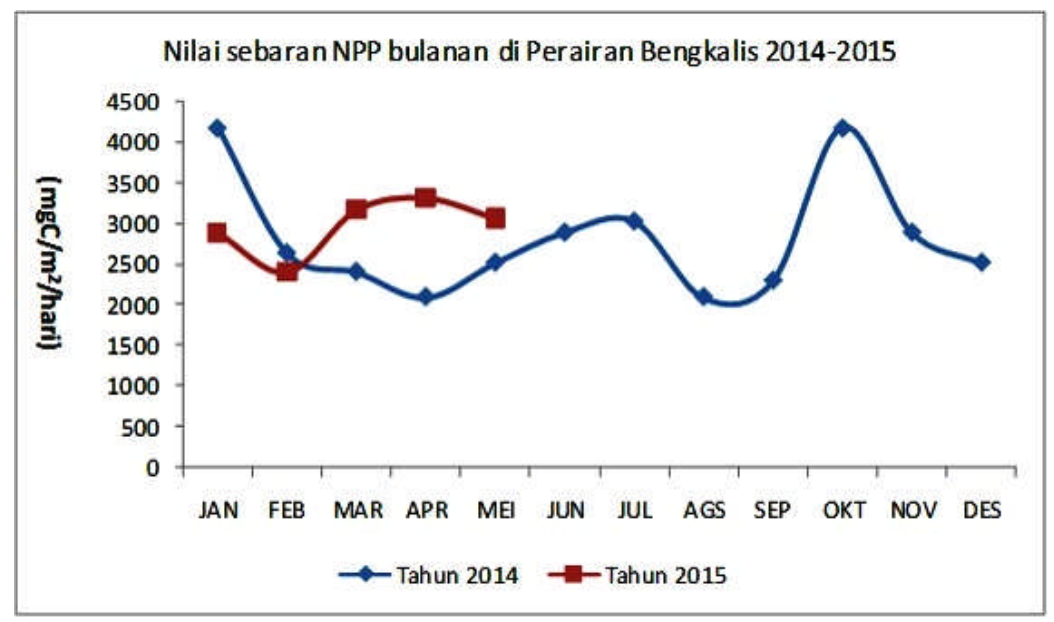

Gambar 5. Fluktuasi sebaran bulanan NPP di perairan Bengkalis pada 2014-2015.

Figure 5. Monthly fluctuation of NPP in Bengkalis waters in 2014-2015.

Tabel 5. Estimasi potensi biomassa ikan berdasarkan nilai NPP perairan Bengkalis pada 2014

Table 5. Estimation of fish biomass potention based on NPP in Bengkalis waters in 2014

\begin{tabular}{|c|c|c|c|}
\hline \multirow[t]{2}{*}{ Bulan/Month } & \multirow{2}{*}{$\begin{array}{l}\mathrm{NPP}(\mathrm{B}) \\
\mathrm{gC} \mathrm{\textrm {m } ^ { - 2 }}\end{array}$} & \multicolumn{2}{|c|}{$\begin{array}{c}\text { Potensi Biomassa Ikan/Potential of fish } \\
\text { biomass }\end{array}$} \\
\hline & & $\mathrm{mgC} \mathrm{m}^{-2}$ & Ton \\
\hline Januari & 288,4 & 865,2 & $7.348,7$ \\
\hline Februari & 239,9 & 719,7 & $6.112,7$ \\
\hline Maret & 316,2 & 948,6 & $8.056,8$ \\
\hline April & 331,1 & 993,3 & $8.436,5$ \\
\hline Mei & 305,9 & 917,7 & $7.794,4$ \\
\hline Juni & 288,4 & 865,2 & $7.348,5$ \\
\hline Juli & 302,0 & 906,0 & $7.695,0$ \\
\hline Agustus & 208,9 & 626,7 & $5.322,8$ \\
\hline September & 229,1 & 687,3 & $5.837,5$ \\
\hline Oktober & 416,9 & $1.250,7$ & $10.622,7$ \\
\hline November & 288,4 & 865,2 & $7.348,5$ \\
\hline Desember & 251,2 & 753,6 & $6.400,6$ \\
\hline Jumlah/Total & $3.466,4$ & 10399,2 & $88.324,3$ \\
\hline Rata-rata/Average & 288.9 & 866.6 & $7,360.4$ \\
\hline \multicolumn{2}{|c|}{$\begin{array}{l}\text { Oleh karena perairan Bengkalis merupakan bagian } \\
\text { daerah kontinen, maka besarnya tingkat tropik yang } \\
\text { digunakan adalah } 3 \text { dan efisiensi ekologis } 15 \% \text { (Tabel } \\
\text { 1). Produksi ikan diperoleh berdasarkan asumsi yang } \\
\text { dikemukakan Eppley \& Peterson (1979) vide Parson }\end{array}$} & \multicolumn{2}{|c|}{$\begin{array}{l}\text { dan berat karbon adalah 20, maka potensi produks } \\
\text { rata-rata ikan (semua jenis: pelagis dan demersal) d } \\
\text { kawasan konservasi terubuk adalah } 50 \% \text { dari potens } \\
\text { rata-rata biomassa yang sebesar } 7.360,4 \text { ton/tahun } \\
\text { yaitu sekitar } 3.680,2 \text { ton/tahun (Tabel } 6 \text { ). }\end{array}$} \\
\hline
\end{tabular}


Tabel 6. Estimasi potensi produksi ikan (pelagis dan demersal) di perairan Bengkalis berdasarkan analisa NPP 2015

Table 6. Estimation of fish production potention (pelagic and demersal) based on NPP in Bengkalis waters 2015

\begin{tabular}{|c|c|c|c|c|}
\hline \multirow{2}{*}{ Lokasi/Location } & \multirow{2}{*}{$\begin{array}{c}\text { Luas } \\
\text { Perairan/Waters } \\
\text { area coverage } \\
\left(\mathrm{km}^{2}\right)\end{array}$} & \multicolumn{2}{|c|}{$\begin{array}{c}\text { Potensi Biomassa Ikan/ } \\
\text { Potential fish biomass }\end{array}$} & \multirow{2}{*}{$\begin{array}{l}\text { Potensi Produks } \\
\text { Ikan/Potential fis } \\
\text { production } \\
\text { (ton)/tahun }\end{array}$} \\
\hline & & $\left(\mathrm{mgCm}^{-2}\right)$ & (ton) & \\
\hline $\begin{array}{l}\text { Perairan Bengkalis } \\
\text { (habitat ikan terubuk) }\end{array}$ & 424,7 & 866,6 & $7.360,4$ & $3.680,2$ \\
\hline
\end{tabular}

\section{Bahasan}

\section{Kondisi Mangrove}

Total luas mangrove yang teridentifikasi dari citra Satelit Landsat 8 (2015) mencapai 11.736,3 Ha, berbeda jauh dengan data Statistik Kab. Bengkalis yang luasannya sekitar 33.016 Ha (Anonim, 2016). $\mathrm{Hal}$ ini terjadi karena dalam penelitian ini tidak memasukan data mangrove dari 2 kecamatan di P. Rupat (tidak terkait langsung dengan habitat ikan terubuk). Namun, angka ini mendekati yang dipublikasikan Bappeda Kab. Bengkalis 2007 dalam Anonim (2015) menyebutkan luasan mangrove di Kab. Bengkalis sekitar $11.481 \mathrm{Ha}$. Khusus di P. Bengkalis saja, luasan mangrove mencapai $15.039 \mathrm{Ha}$, sekitar $9.133 \mathrm{Ha}$ berada di wilayah pantai utara yang berbatasan dengan Sel. Malaka (Hakim, 2003). Jika mengacu kepada kajian Hakim (2003), berarti telah terjadi penurunan luasan mangrove di $\mathrm{P}$. Bengkalis seluas $4.470,8 \mathrm{Ha}$ (dalam waktu 12 tahun) atau terjadi kehilangan mangrove seluas $372,5 \mathrm{Ha} /$ tahun. Angka ini lebih besar dari yang dilaporkan Fikri (2006) yang hanya $201,2 \mathrm{Ha} /$ tahun (pengamatan 1992-2002).

Dari sebaran spasialnya (Gambar 4), menunjukkan mangrove di sisi utara $P$. Bengkalis yang menghadap Sel. Malaka (Kec. Bengkalis) tidak ditemukan lagi atau ditemukan sedikit. Demikian juga di Kec. Bantan, mangrove hanya terdeteksi di sepanjang aliran sungai. Padahal menurut Hakim (2003), pada 2002 di sepanjang pantai ini terdapat mangrove seluas 9.133 $\mathrm{Ha}$. Diduga, hilangnya mangrove di sisi utara pantai Bengkalis yang menghadap ke Selat Malaka selain akibat aktivitas manusia (aktivitas ekonomi dan pemukiman) juga disebabkan oleh gelombang yang cukup besar, sehingga tidak ada sedimentasi sebagai lahan untuk tumbuh. Hal ini diperkuat dengan informasi bahwa dalam satu dekade terakhir, kerusakan fisik pantai akibat abrasi dan erosi di Kabupaten Bengkalis dinyatakan meningkat, dengan rata-rata laju abrasi cukup tinggi mencapai sebesar $3,16 \mathrm{~m} /$ tahun (http: //cekau.blogspot.co.id/2013/02). Pada garis pantai yang menghadap langsung ke lokasi habitat terubuk (Selat Bengkalis, Selat Padang dan Sungai Pakning), menunjukkan degradasi man- grove karena aktivitas manusia seperti pemukiman, tambak, pembangunan pelabuhan dan lain-lainnya karena berada di lokasi padat penduduk yaitu Kota Bengkalis. Hamparan mangrove yang tipis di Kecamatan Bukit Batu dan Siak Kecil pada saat survei (Agustus 2015) sebagian besar sudah terkonversi menjadi tanah kering yang siap didirikan bangunan.

Kerapatan mangrove yang tinggi di tiga muara sungai di Kec. Bantan yang terlihat dari citra satelit, diduga pengaruh pasang surut yang menjamin masuknya air laut dan ketersediaan air tawar dari sungai menjadikan kawasan tersebut sebagai hutan mangrove yang subur. Sementara sebaran mangrove yang tersisa di habitat terubuk di Kec. Bengkalis, umumnya berada pada daerah yang relatif terlindung dari gelombang yang besar dan didukung sumber sedimentasi.

\section{Kondisi Perairan}

Sebagai perairan dangkal dan berada di estuaria Sungai Siak, kawasan konservasi ikan terubukmendapat pengaruh sedimentasi yang cukup tinggi. Dua sumber sedimen berasal dari buangan limbah penggergajian kayu dari pabrik di aliran S. Siak dan endapan abrasi akibat degradasi lingkungan sekitar (Wahyu, 2015). Selain itu ditambah dengan limbah kulit kayu bahan baku pulp dari kapal tongkang yang melintas di S. Siak ikut dibuang ke perairan ini (Efizon, 2016: komunikasi pribadi). Kondisi tersebut berpengaruh langsung terhadap tingkat kecerahan perairan yang dalam penelitian ini sangat rendah (ratarata 0,5-0,9 m). Bahkan, Anonim (2014) menyatakan perairan Bengkalis massa airnya selalu berwarna coklat dan memiliki zero visibility. Kondisi ini diperparah oleh struktur dasar perairan yang didominasi lumpur dan pasir.

Kisaran nilai sebaran suhu perairan di kawasan konservasi terubuk berada pada rentang 29,15-31,87 ${ }^{\circ} \mathrm{C}$. Angka ini lebih hangat dari yang dinyatakan Nontji (2002) bahwa perairan Indonesia yang berada di lingkungan tropis, suhunya berkisar $28-31^{\circ} \mathrm{C}$. Lebih tingginya suhu perairan kawasan konservasi ikan 
terubuk ini, disebabkan karena relatif dangkal serta mendapat aliran massa air tawar dari muara Sungai Siak dan perluasan massa air Selat Lalang yang mendapat pengaruh massa air tawar dari muara Sungai Kampar di bagian barat. Karakteristik kedua massa air tersebut cenderung lebih hangat akibat pengaruh aktivitas daratan. Kondisi ini pula yang menyebabkan salinitas di perairan ini tergolong rendah, berkisar 26,50-31,25 ppt. Fluktuasi salinitas umumnya tergantung musim, dimana salinitas rendah terjadi pada musim penghujan (September-Januari) dan salinitas tinggi pada musim kemarau (FebruariAgustus). Hal yang sama terjadi pada nilai sebaran $\mathrm{pH}$ (rata-rata $\mathrm{pH} 7$ ), dimana nilai $\mathrm{pH}$ paling rendah (pH 6,3) ditemukan di perairan Selat Padang/Pakning dekat muara Sungai Siak pada periode musim penghujan, terkait dominasi air gambut. Nilai sebaran oksigen terlarut/DO yang berkisar 3,90-4,98 mg/l ini, tergolong rendah, di bawah Baku Mutu Air Laut untuk kehidupan biota yang dikeluarkan Kementerian Lingkungan Hidup (KLH) yaitu >5 ppm (Anonim, 2004). Angka tersebut juga jauh lebih rendah dibandingkan nilai normal DO di lautan yang menurut Sutamihardja (1987) berkisar 5,7-8,5 ppm.

Meskipun dari parameter fisik dan kimia, kualitas lingkungan perairan kawasan konservasi terubuk cenderung kurang baik, namun dari kelimpahan fitoplankton yang berkisar 23.584-95.616 sel/l dan kekayaan jenis 32-52 genera, menandakan perairan ini cukup subur. Menurut Raymont (1963), tingginya kelimpahan fitoplankton memiliki hubungan positif dengan kesuburan dan produktifitas perairan. Sebagai pembanding, kelimpahan fitoplankton di estuaria Sungai Porong berkisar 18.077 sel/l-29.305 sel/I terdiri dari 16 genera (Abida, 2010) dan penelitian Wisha et al, (2016) di perairan yang sama menemukan jumlah yang lebih besar mencapai 35.243 Ind/l. Sementara di perairan Berau lebih tinggi sekitar 75.746 sel// terdiri dari 28 genera (Aryawati et al., 2011). Angka ini mendekati kondisi di perairan Bengkalis baik dari kelimpahannya maupun jumlah jenis fitoplanktonnya.

\section{Produktivitas Primer dan Potensi Produksi Ikan}

Kisaran nilai sebaran NPP sebesar 2.089-4.169 $\mathrm{mgC} / \mathrm{m}^{2} /$ hari di kawasan konservasi ikan terubuk, tergolong tinggi. Hal ini menandakan bahwa tingkat produktivitas primer perairan ini juga tinggi. Perlu menjadi catatan adalah input utama dari NPP adalah konsentrasi klorofil-a dari fitoplankton. Perlu diingat bahwa perairan Bengkalis termasuk daerah dengan tingkat kekeruhan tinggi, dimana estimasi dari model klorofil-a cenderung over-estimate. Namun hasil pengukuran kelimpahan fitoplankton secara in-situ yang berkisar 23.584-95.616 sel/I mendukung bukti tingginya tingkat produktivitas perairan ini. Berpedoman kepada Landner (1978), habitat ikan terubuk ini termasuk kategori perairan eutrofik (kesuburan tinggi) dengan kelimpahan fitoplankton $>15.000$ ind/l. Dengan demikian logis jika potensi biomassa ikan di perairan Bengkalis berdasarkan nilai NPP yang sebesar $866,6 \mathrm{mgCm}^{-2}$, lebih tinggi dibandingkan di lokasi sampling Laut Cina Selatan (Masrikat et al., 2009).

Selanjutnya, nilai potensi ikan berdasarkan analisa NPP yang sebesar 3.680,2 ton/tahun (Tabel 6) diasumsikan sebagai potensi sumberdaya (standing stock) seluruh kelompok jenis ikan (pelagis dan demersal) di perairan ini. Mengingat bahwa nilai NPP yang dihitung, mewakili seluruh lapisan perairan karena perairannya dangkal (estuaria).

Berdasarkan data statistik perikanan Kabupaten Bengkalis, estimasi potensi ikan di lokasi penelitian sebesar 2727 ton/tahun terdiri dari 1684 ton/tahun ikan pelagis dan 1043 ton/tahun ikan demersal (Anonim, 2013). Adapun estimasi besaran biomassa ikan terubuk berdasarkan analisa akustik, pada tahun 2015 sebesar 80,06 ton (Anonim, 2015).

Estimasi potensi sumberdaya ikan berdasarkan analisa NPP di perairan Bengkalis ini menunjukkan over estimate. Hal ini dapat terjadi karena perairan Bengkalis memiliki tingkat kekeruhan yang tinggi. Sesuai dengan pernyataan Tang et al. (2003), overestimasi penghitungan NPP di suatu perairan bisa terjadi karena pengaruh kekeruhan.

Angka hasil penghitungan tersebut bisa menjadi gambaran awal mengenai tingginya potensi produksi terubuk di perairan Bengkalis. Namun, untuk mempertahankan keberlanjutan sumber daya, perlu upaya perbaikan kondisi lingkungan perairan untuk menekan pencemaran dan kekeruhan serta pemulihan tutupan mangrove disamping menegakkan aturan konservasi yang selama ini sudah dilakukan.

\section{KESIMPULAN}

Kondisi perairan kawasan konservasi ikan terubuk Bengkalis memiliki tingkat kecerahan rendah (keruh), nilai sebaran $\mathrm{pH}$ dan oksigen terlarut juga rendah (di bawah Baku Mutu Air Laut untuk kehidupan biota), serta berpotensi terancam cemaran aktivitas ekonomi sepanjang aliran Sungai Siak maupun di sekitar kawasan konservasi ikan terubuk itu sendiri. Degradasi mangrove di sepanjang pantai Bengkalis dengan laju kehilangan yang cukup tinggi, menyebabkan erosi dan abrasi (meningkatkan kekeruhan) serta hilangnya fungsi ekologis mangrove sebagai daerah asuhan larva. Secara umum, perairan ini tergolong subur 
(eutrofic) dengan kelimpahan dan kekayaan jenis fitoplankton tinggi, didukung tingkat produktifitas primer tinggi serta potensi produksi semua jenis ikan berdasarkan analisa NPP mencapai 3.680,2 ton/ tahun. Potensi produksi terubuk berdasarkan analisa akustik pada tahun yang sama (2014) sebesar 80,06 ton . Kondisi ini memberi harapan bahwa sumber daya perikanan terubuk cukup potensial dan penting dipertahankan melalui perbaikan kualitas perairan serta pemulihan tutupan mangrove.

\section{PERSANTUNAN}

Paper ini bagian hasil kegiatan penelitian yang dibiayai APBD Pemerintah Kabupaten Bengkalis (Dinas Kelautan dan Perikanan) TA2015 dengan judul kegiatan "Analisa Daya Dukung Lingkungan Kawasan Konservasi Ikan Terubuk". Penulis mengucapkan terima kasih kepada Pemerintah Kabupaten Bengkalis melalui Dinas Kelautan dan Perikanan Kabupaten Bengkalis yang membiaya dan memfasilitasi penelitian ini. Terima kasih juga disampaikan kepada segenap tim yang terlibat.

\section{DAFTAR PUSTAKA}

Abida, I.W. (2010). Struktur komunitas dan kelimpahan fitoplankton di Perairan Muara Sungai Porong Sidoarjo. Jurnal Kelautan. Univ. Trunojoyo, Madura. 3(1), 36-40.

Anonim. (2004). Keputusan Menteri Lingkungan Hidup No. 51 Tahun 2004, tentang Baku Mutu Air Laut. Menteri Negara Lingkungan Hidup.

Anonim. (2013). Laporan Akhir Kegiatan Penetapan Kuota Penangkapan Ikan di Perairan Kabupaten Bengkalis. Kerjasama Penelitian antara Dinas Kelautan dan Perikanan Kabupaten Bengkalis dengan Balai Penelitian Perikanan Laut (tidak dipublikasikan).

Anonim. (2014). Ekosistem dan Sumberdaya Hayati Perairan Bengkalis. KP3K-Kementerian Kelautan dan Perikanan (www.kp3k.kkp.go.id; diakses pada tanggal 15 Juli 2017 pukul 17.15).

Anonim. (2015). Status Sumber daya Terubuk Bengkalis 2015. Bagian Laporan Akhir Penelitian Analisa Daya Dukung Lingkungan Kawasan Konservasi Ikan Terubuk. Kerjasama Penelitian antara Dinas Kelautan dan Perikanan Kabupaten Bengkalis dengan Balai Penelitian Perikanan Laut (BPPL), Puslitbangkan, KKP. p. 143.
Anonim. (2016). Kabupaten Bengkalis Dalam Angka. Badan Pusat Statistik Kabupaten Bengkalis. ISSN: 0215-3866. xxviii + 204 hal.

Aryawati, R \& H. Thoha. (2011). Hubungan Kandungan Klorofil-a dan Kelimpahan Fitoplankton di Perairan Berau Kalimantan Timur. Jurnal Maspari. 2 (2), 89-04.

Behrenfeld, M. J. \& P. G. Falkowski. (1997). Photosynthetic rates derived from satellite-based chlorophyll concentration. Limnol. Oceanogr. 42, 1-20.

Campbell, J. D. A., Armstrong, R., Arrigo, K., Balch, W., Barber, R., Behrenfeld, M., Bidigare, R., Bishop, J., Carr, M.-E., Esaias, W., Falkowski, P., Hoepffner, N., Iverson, R., Kiefer, D., Lohrenz, S., Marra, J., Morel, A., Ryan, J., Vedernikov, V., Waters, K., Yentsch, C., \& Yoder, J. (2002). Comparison of algorithms for estimating ocean primary production from surface chlorophyll, temperature, and irradiance. Global Biogeochem. Cycles, 16(3), doi:10.1029/2001GB001444.

Darmawan, A., Syamsul, B.L., \& Suraji. (2014). Status pengelolaan efektif kawasan konservasi perairan pesisir dan pulau-pulau kecil di Indonesia: Profil 113 Kawasan Konservasi Perairan Pesisir dan Pulau-Pulau Kecil. Direktorat Konservasi Kawasan dan Jenis Ikan (KKJI). Direktorat Jenderal Kelautan, Pesisir dan Pulau-pulau Kecil. Kementerian Kelautan dan Perikanan Republik Indonesia. ISBN: 978-602-7913-22-6.

Efizon, D. (2016). Komunikasi Pribadi. Fakultas Perikanan dan Kelautan. Universitas Riau. Pekanbaru.

Efizon, D, \& Alit, H.Y. (2013). Dampak KepMen KP Nomor Kep.59/MEN/2011 Tentang Penetapan Status Perlindungan Terbatas Jenis Ikan Terubuk (Tenualosa macrura) dalam Meningkatkan Populasi Ikan Terubuk di Provinsi Riau. Bahan Presentasi (tidak dipublikasikan).

Efizon, D., Otong, S.D., Yayat, D., \& Bachrulhajat, K. (2012). Kelimpahan populasi dan tingkat eksploitasi ikan terubuk (Tenualosa macrura) di Perairan Bengkalis, Riau. Jurnal Berkala Perikanan Terubuk, 40(1), $52-65$.

Fajri, N.E. \& A. Kasry. (2013). Kualitas perairan muara sungai siak ditinjau dari sifat fisik-kimia dan makrozoobentos. Berkala Perikanan Terubuk, 41(1), 37-52. 
Fikri, R. (2006). Aplikasi penginderaan jauh untuk mendeteksi perubahan mangrove di Pulau Bengkalis Kabupaten Bengkalis Propinsi Riau. Skripsi Fakultas Perikanan dan IImu Kelautan Universitas Riau, Pekanbaru. Tidak dipublikasikan. p. 154.

Green, E.P., Clark, C.D., \& Edwards, A.J. (2000). Image classification and habitat mapping. In Remote Sensing Handbook for Tropical Coastal Management, A.J. Edwards (Ed.), pp. 141-154 (Paris: UNESCO).

Hakim, I. (2003). Hubungan kerusakan hutan mangrove dengan Abrasi, studi kasus: Pantai Utara Pulau Bengkalis, Propinsi Riau. Tesis. Universitas Indonesia (tidak dipublikasikan: http://lib.ui.ac.id/ opac/ui/).

Kerusakan Ekosistem Mangrove di Wilayah Riau, Butuh Pendampingan Masyarakat. Berita online dari web: http://cekau.blogspot.co.id/2013/02/ kerusakan-ekosistem-mangrove-di-wilayah.html

Landner, K. (1978). Ecology: The Experimental Analysis of Distribution and Abudance (p. 380). Harper and Row.New York.

Levinton, J. S. (1982). Marine Ecology (p. 526). Prentice-Hall, Inc., Englewood Cliffs, N.J.

Masrikat, J.A.N., Indra, J., Budhi, H.I., \& Dedi S. (2009). Estimasi standing stock sumberdaya ikan berdasarkan kandungan klorofil-a. J. Lit. Perik. Ind. 15 (3), 257-266.

Merta, G.S., Suwarso, Wasilun, K. Wagiyo, E.S. Girsang \& Suprapto. (1999). Status populasi dan bio-ekologi ikan terubuk Tenualosa macrura (Clupeidae) di Propinsi Riau. J. Lit. Perik. Ind. 5(3), 15-29.

Parson, T. R, Takahashi, M., \& Hargrave, B. (1984). Biological oseanographic processes (p. 330). Third Edition. Pergamon Press. UK.

Purwadhi, S. H. (2001). Interpretasi Citra Digital. Jakarta: Grasindo.
Raymont, J.E.G. (1963). Plankton and productivity in the oceans. Pergamon Press, Oxford, London. viii $+660 \mathrm{p}$.

Setiawan, D. (2008). Struktur Komunitas Makrozoobentos Sebagai Bio-indikator Kualitas Lingkungan Perairan Hilir Sungai Musi. Sekolah Pascasarjana Institut Pertanian Bogor. Tesis S2. 175 hal. Tidak dipublikasikan.

Short, N. M. (1982). The landsat tutorial workbookBasics of satellite remote sensing. Greenbelt, Md., Goddard Space Flight Center, NASA Reference Publication 1078.

Strurges, H. (1926). The choice of a class-interval. J. Amer. Statist. Assoc, 21, 65-66.

Sutamihardja, R.T.M., (1987). Kualitas dan Pencemaran Lingkungan (p. 92). Fakultas Pascasarjana, Institut Pertanian Bogor.

Suwarso \& I. G. Merta. (2003). Penurunan Populasi dan Alternatif Pengelolaan Ikan Terubuk, Tenualosa macrura (Clupeidae), di Propinsi Riau. J. Lit. Perik. Ind. 6(2), 25- 36.

Tang, D.L., Kawamura, H., Lee, M.A., \& Dien, T.V. (2003). Seasonal and spatial distribution of chlorophyll-a concentrations and water conditions in the Gulf of Tonkin, South China Sea. Remoting Sensing of Environmen. t 85, 475-483.

Wahyu, D.S. (2015). Pelaksanaan Peraturan Bupati Kabupaten Bengkalis Nomor 15 Tahun 2010 Tentang Kawasan Konservasi Perikanan Ikan Terubuk Tahun 2011-2014. JOM FISIP Universitas Riau. 2(2), 1-15.

Wisha, U.J., M. Yusuf \& Lilik Maslukah. (2016). Kelimpahan Fitoplankton dan Konsentrasi TSS Sebagai Indikator Penentu Kondisi Perairan Muara Sungai Porong. Jurnal Kelautan Volume 9, No. 2, Oktober 2016 ISSN: 1907-9931 (print), 2476-9991. p. $122-129$. 
Kualitas Lingkungan Perairan dan Potensi Produksi Ikan Kawasan Konservasi Terubuk.......(Amri, K., et al)

Lampiran 1. Citra NPP perairan Bengkalis dan sekitarnya Januari 2014-Mei 2015

Appendix 1. Net Primary Productivity Imagery of Bengkalis waters in January 2014-May 2015

Citra NPP Butanan Januari-Junl 2014
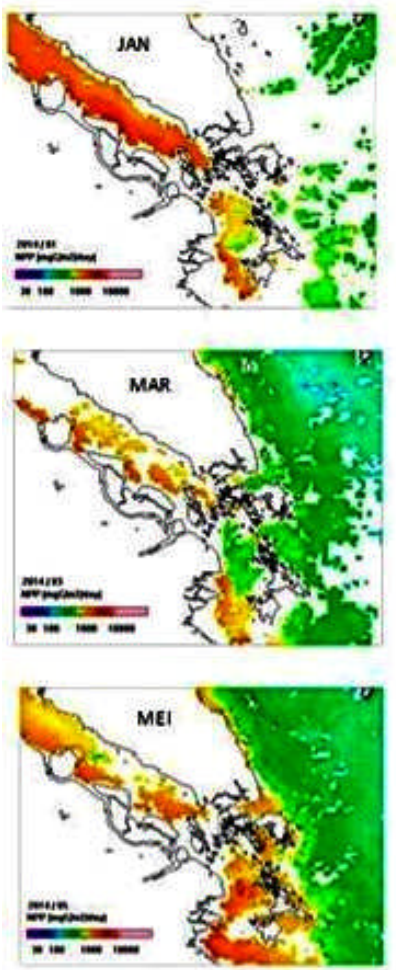
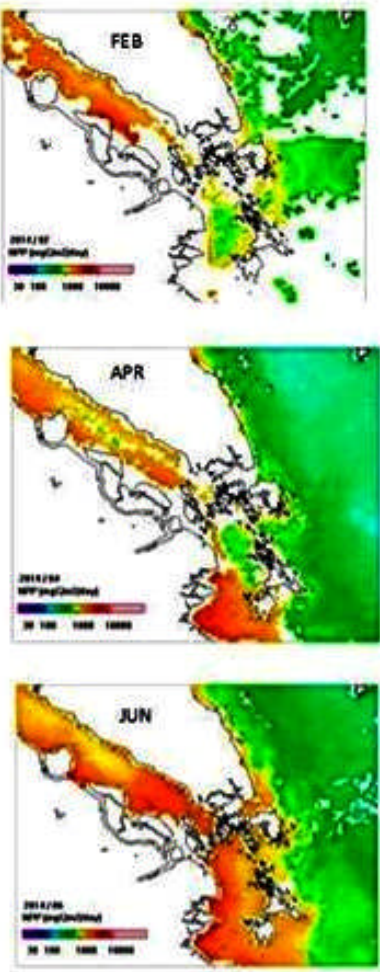

Citra NPP Bulanan Januart-Met2015
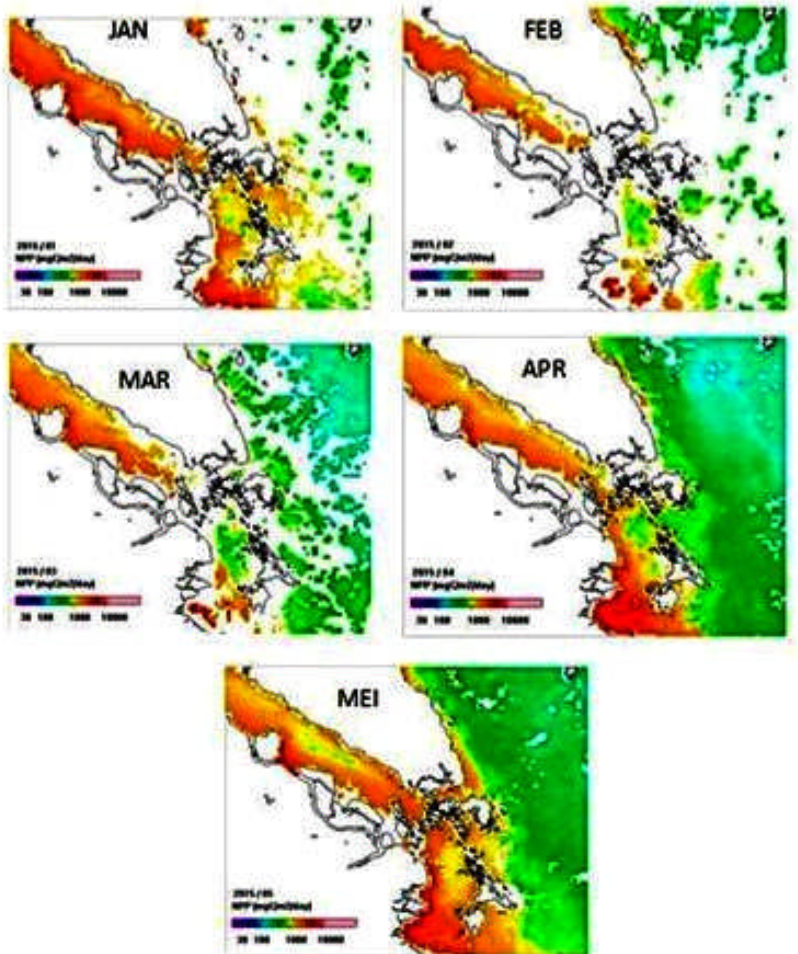

Ctra NPPBulanan Juli-Desember 2014
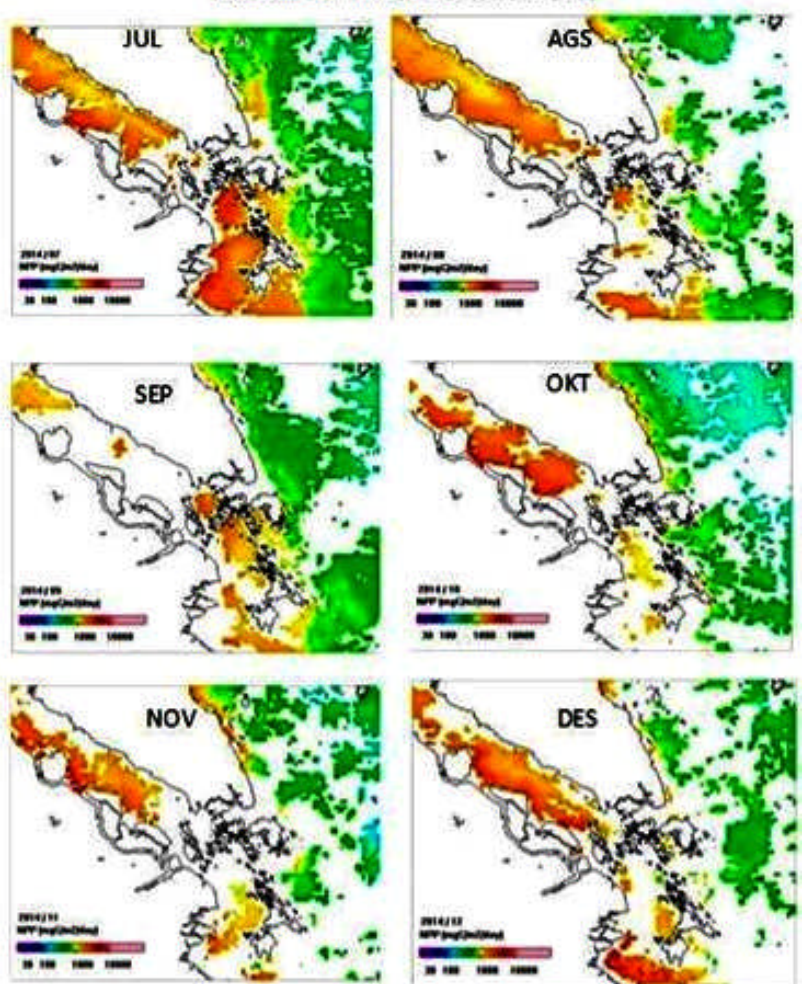